\title{
Comparison of the economic development of countries spreading Spanish culture
}

\author{
Mikhail Savelyev ${ }^{1}$, Andrey Savchenko ${ }^{1}$, Vladimir Koretsky², Olga Titova $^{2}$, and Andrey \\ Bryndin $^{1}$ \\ ${ }^{1}$ Association for Methodological Support of Business Activity and Social Development Mitra, \\ Pushkinskaya Street, 241, Izhevsk, Russia \\ ${ }^{2}$ Kalashnikov Izhevsk State Technical University, Studencheskaya Street, 7, Izhevsk, Russia
}

\begin{abstract}
An analysis of the risks and rates of development of the countries with Spanish culture for the period from 1820 showed that the influence of culture and institutions on these parameters of development is not detected. Neither the former metropolis, nor its largest former colonies were among the leaders of the world's economic development, have not cultivated a special institutional development model that would enable sustainable internal growth. In general, it can be stated that the countries of Spanish culture became the periphery of Western civilization, which disabled them to become either independent civilizations or integrate into the core of the development of the global West.
\end{abstract}

\section{Introduction}

The paper examines the development of the economy of Spain, the former colonies of the Spanish Empire and countries associated with Spain by economic unions or other significant economic ties, including migration. With the colonies, Spain was united by common institutions of government. Some of the colonies were settled by immigrants from the metropolis, therefore, Spain has a common culture with this group. Countries that have entered into economic alliances with Spain and with active migration exchanges have varying degrees of cultural and institutional affinity with Spain. After the collapse of the Spanish Empire, part of the former colonies united into economic alliances, which brought their institutional models together, and the other part entered into alliances with countries that had no previous connection with Spain, which could have affected a faster departure from colonial management traditions.

In addition, Spain has been a member of military-political and economic alliances for a long time. With these countries, it developed similar institutions of governance, and joint political decisions synchronized their economic development. The countries of this group had different cultural affinities with Spain.

The influence of culture on economic development has been actively studying. Thus, a group of Russian researchers concluded that Russian culture holds back the country's economic development $[1,2,3,4]$. These works are supported by some empirical data $[5,6$, $7,8,9]$. In these studies, there is an elementary violation of logic: if culture and laws do not correlate to each other and slow down economic development, then researchers inscrutably jumped in conclusion that it is more convenient to change or replace the culture. The idea 
that it is more natural to alter laws than culture has not been considered by these researchers for some reason.

Among the ideologically not engaged, but culturally determined studies of culture, there are even textbooks [10]. For reviews and studies of management practices and organizational culture, there are numerous works $[11,12,13,14]$. Empirical studies of innovation activity associate it with political institutions [15], the level of economic freedom [16], corruption [17], the quality of formal $[18,19]$, and informal [20] institutions, as well as social capital [21]. The essential drawback of such studies is lax concept of the mechanism of the influence of culture on economic development and no answer the question how to measure the influence of culture and institutions.

Studies of social and economic processes in Spain and the countries of the Spanish world were carried out in works [1, 22, 23, 24].

This study examines the hypothesis about the presence or absence of similarities between the economic development of the countries of the Spanish world and the allies of Spain: if the cultural and institutional proximity of these countries affect the type of economic development and how quickly postcolonial institutions lose their influence in the former colonies.

This hypothesis was previously put forward in our works on institutional and cultural features of economic development, both in the theoretical models and in the phenomenological description of various historical and cultural communities in the terms of civilizations and cultures [25].

\section{Materials and methods}

A feature of the research methodology is the use for assessing economic development, in addition to the usual indicators of economic growth (growth rates of real GDP), also indicator of stability or risks of this development which is the standard deviations (SD) of the growth rates of real GDP. The periods of risk assessment define the historical periods of the development of Spain, including its entire economic cycles:

- the period of the collapse of the Spanish Empire, the civil war and the first republic (until 1879),

— stabilization period before defeating in the war with the USA (1880-1896),

- period of stagnation (1897-1926),

- period of crises, coups and wars (1927-45),

— the period of isolation of the Francoist dictatorship (1946-1959),

— period of an economic miracle under the dictatorship (1960-1975),

- the period of integration into the European Union (since 1976), in which two fundamentally different stages can be distinguished: development and stagnation (since 1994).

This approach allows the quality of economic decisions and their implementation in different economic models of one particular culture, in this case Hispanic, to be assessed. This method was proposed in our study of the stability of territories [26].

This research method was applied in the study of the economic development of Russia in the imperial, Soviet and modern historical periods [27], together with factorial and functional analysis, it was applied concerning the study of the quality of governance of the post-Soviet governments of Russia [28], as well as in the comparative analysis of German-speaking [29], French-speaking [30], Portuguese-speaking [31] and newly industrialized countries [32].

The data sources are Angus Maddison Historical Statistics database up to 2008 [33], the Conference Board, Total Economy Database [34, 35] from 2009 to 2020. 
All possible values of indicators of growth and risk of economic development occupy the following distribution area (see Fig. 1). The characteristics of the individual parts of this area are given in Table 1. Thus, the type of economic development of countries in a particular period can be determined.

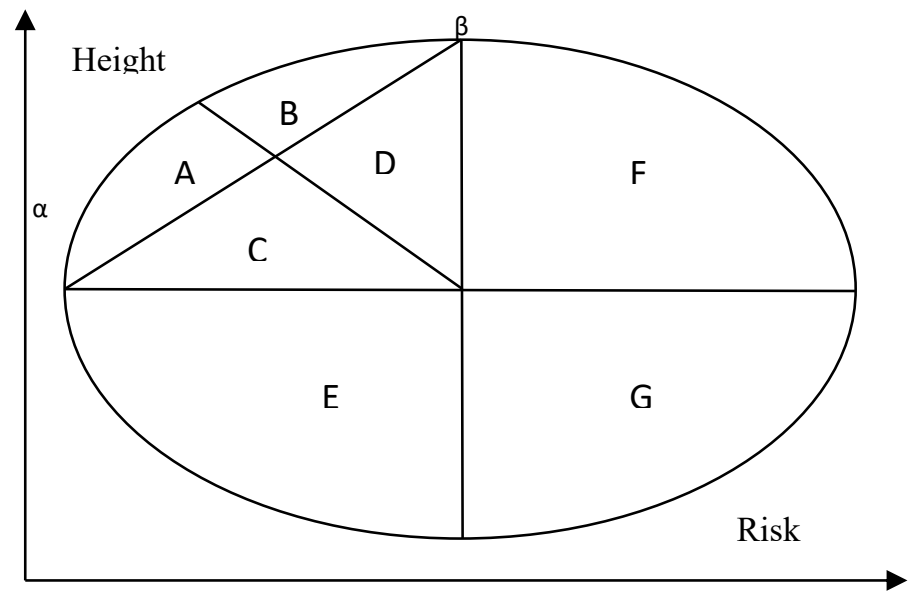

Fig. 1. Scheme of types of effective and sustainable development.

Source [26].

Table 1. Characteristics of elements of the area of distribution of indicators of growth and risk of economic development.

\begin{tabular}{|l|l|l|}
\hline $\begin{array}{c}\text { Designations in } \\
\text { the diagram } \\
\text { (Fig. 1) }\end{array}$ & \multicolumn{1}{|c|}{ Value } & \multicolumn{1}{|c|}{ Comment } \\
\hline$\alpha$ & Minimum risk point & $\begin{array}{l}\text { At this point, the territory demonstrates the } \\
\text { minimum risks from among the studied } \\
\text { phenomena. }\end{array}$ \\
\hline$\beta$ & Point of maximum growth & $\begin{array}{l}\text { At this point, the territory demonstrates the } \\
\text { maximum growth among the studied } \\
\text { phenomena. }\end{array}$ \\
\hline $\mathrm{A} \beta$ curve & $\begin{array}{l}\text { The curve of balanced } \\
\text { (effective) development }\end{array}$ & $\begin{array}{l}\text { This curve contains the phenomena for which, } \\
\text { for a given growth, there are no lower risks } \\
\text { and for a given risk there is no greater growth, } \\
\text { and resources are used most optimally. }\end{array}$ \\
\hline Area ABCDF & Growth area (innovation) & $\begin{array}{l}\text { In this area, economic growth is higher than } \\
\text { with minimal risk - the most important sign of } \\
\text { innovative development }\end{array}$ \\
\hline Area EG & $\begin{array}{l}\text { Conservation area (rejection } \\
\text { of innovation) }\end{array}$ & $\begin{array}{l}\text { Here growth is lower than with minimal risk - } \\
\text { innovation is not enough }\end{array}$ \\
\hline Area ABCDE & Stability region & $\begin{array}{l}\text { Risks are lower than at maximum growth - the } \\
\text { most important sign of the institutional } \\
\text { maturity of a society }\end{array}$ \\
\hline Area FG & $\begin{array}{l}\text { The area of institutional } \\
\text { underdevelopment } \\
\text { (instability) }\end{array}$ & $\begin{array}{l}\text { Risks are higher than with maximum growth - } \\
\text { institutions are not able to ensure the } \\
\text { sustainability of economic growth }\end{array}$ \\
\hline Development area & $\begin{array}{l}\text { Growth is higher than with the minimum risk, } \\
\text { and the risk is lower than with the maximum } \\
\text { growth - the territory is institutionally } \\
\text { developed and implements innovations }\end{array}$ \\
\hline
\end{tabular}


Table 1. Continued.

\begin{tabular}{|l|l|l|}
\hline Area F & $\begin{array}{l}\text { The area of theft } \\
\text { (kleptocracy) }\end{array}$ & $\begin{array}{l}\text { Innovations are carried out, but the risks are } \\
\text { higher than at maximum growth due to } \\
\text { institutional underdevelopment }\end{array}$ \\
\hline Area E & $\begin{array}{l}\text { Mafia area (institutional } \\
\text { conservation, institutional } \\
\text { autism) }\end{array}$ & $\begin{array}{l}\text { There is a rejection of innovation, but high } \\
\text { institutional development ensures a low level } \\
\text { of risks }\end{array}$ \\
\hline Area G & Degradation area & $\begin{array}{l}\text { Institutional underdevelopment and rejection } \\
\text { of innovation leads to the degradation }\end{array}$ \\
\hline Area AC & $\begin{array}{l}\text { Area of conservative } \\
\text { development }\end{array}$ & $\begin{array}{l}\text { Risk and growth indicators are closer to the } \\
\text { point of minimum risk than to the point of } \\
\text { maximum growth - when managing the } \\
\text { territory, the most attention is paid to } \\
\text { institutions, not innovation }\end{array}$ \\
\hline Area BD & $\begin{array}{l}\text { Aggressive development } \\
\text { area }\end{array}$ & $\begin{array}{l}\text { Risk and growth indicators are closer to the } \\
\text { point of maximum growth than to the point of } \\
\text { minimum risk - when managing the territory, } \\
\text { the greatest attention is paid to innovations, } \\
\text { not institutions }\end{array}$ \\
\hline Area AB & $\begin{array}{l}\text { All resources of the territory are involved in } \\
\text { the development }\end{array}$ \\
\hline Area CD & Elite development area & $\begin{array}{l}\text { Not all resources of the territory are involved } \\
\text { in the development, a significant part of the } \\
\text { resources are not used (consumed by the } \\
\text { elite), but, if necessary, can be directed to } \\
\text { increase growth and/or reduce risk }\end{array}$ \\
\hline
\end{tabular}

Source [26].

To normalize the point of minimum risk and maximum growth, the following methodological principle was formulated [26]:

- the country with the smallest growth was selected from the group of countries with the lowest risk;

- from the group of countries with the highest growth, the country with the highest risk was selected.

In line with this principle in the study of newly industrialized countries [32] in the period since 1950, the following points were selected: maximum - China according to the official data of national statistics [35] for the period 1951-2019 and the global indicator for 19512008 [33]. The latter indicator clearly defines the long-term boundary between old and newly industrialized countries.

In the study of global indicators for the period since 1930, this method has been applied to every global economic cycle [26]. The linearization of these data showed very close characteristics with the line adopted in the study of newly industrialized countries [32], with the maximum discrepancies revealed in the period before 1950. For our study, the standards for the period since 1950 are taken from the other study [32].

An analysis of the indicators of the first half of the 20th century showed that it is not possible to determine the standards in this period in a similar way due to the incompleteness of the data of most countries and the very large scatter of data due to the two world wars. The period 1830-1900 proved to be much more stable, if the data of countries where mass colonization had begun (Australia, Canada, etc.) are excluded from, and data on countries that were beyond industrialization in this period are practically absent. For this study, data from Belgium for 1893-1903 with the minimum risk of the 19th century were selected as the standards, and the USA for the period 1880-1885 was selected as the point of maximum growth, because countries with high risk and growth are countries of mass agrarian colonization. In addition, the defined line turned out to be parallel with the line of the period after 1950, which is additional evidence of the correctness of the choice of this standard. 


\section{Results and discussion}

The results of the study are shown in Figure 2. The graphs before 1945 show the normative lines of the 19th century, then - the second half of the 20th century. In the first four graphs, the dotted line indicates the line separating the areas of egalitarian and elite development for the available sample of countries.
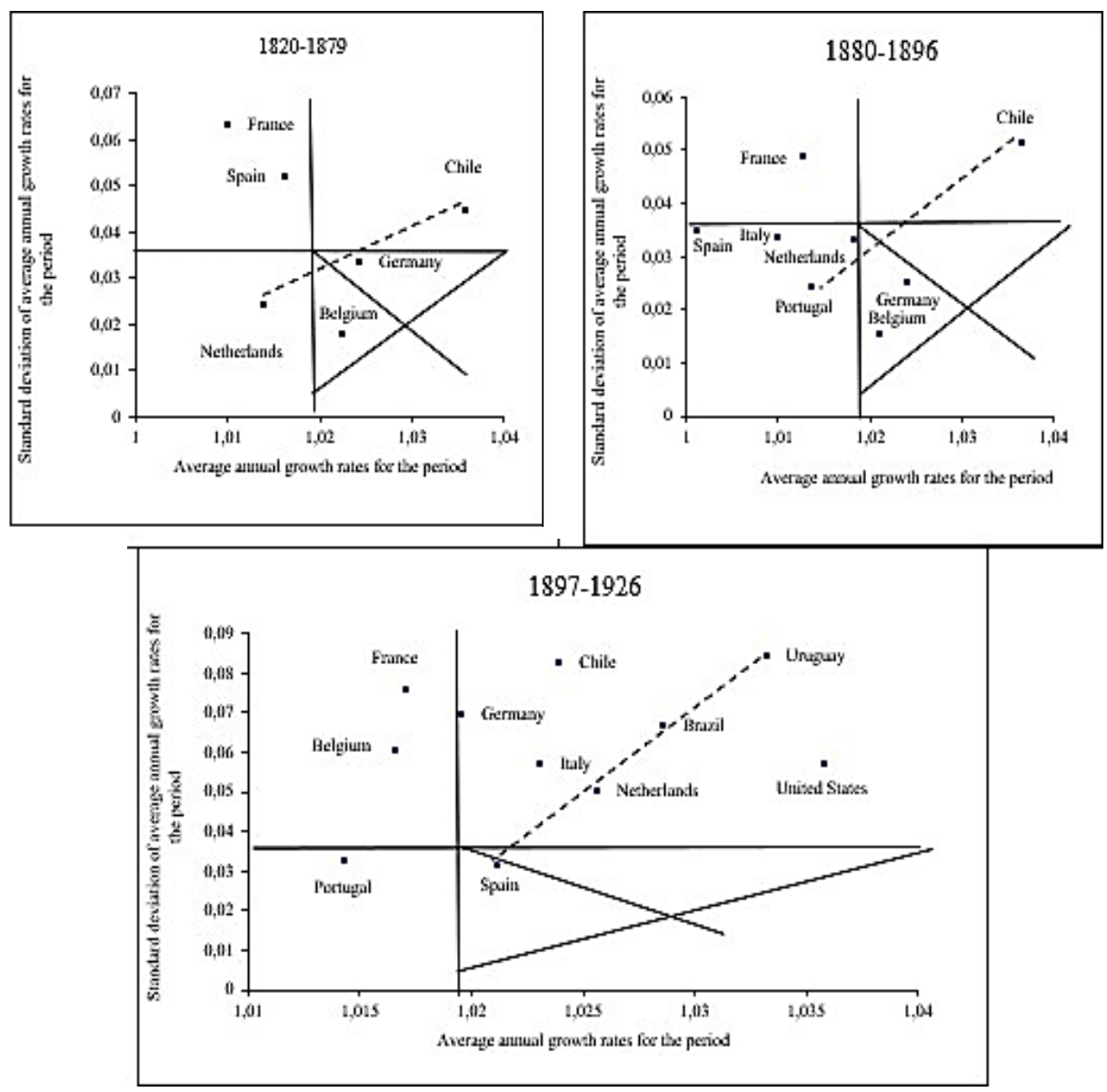


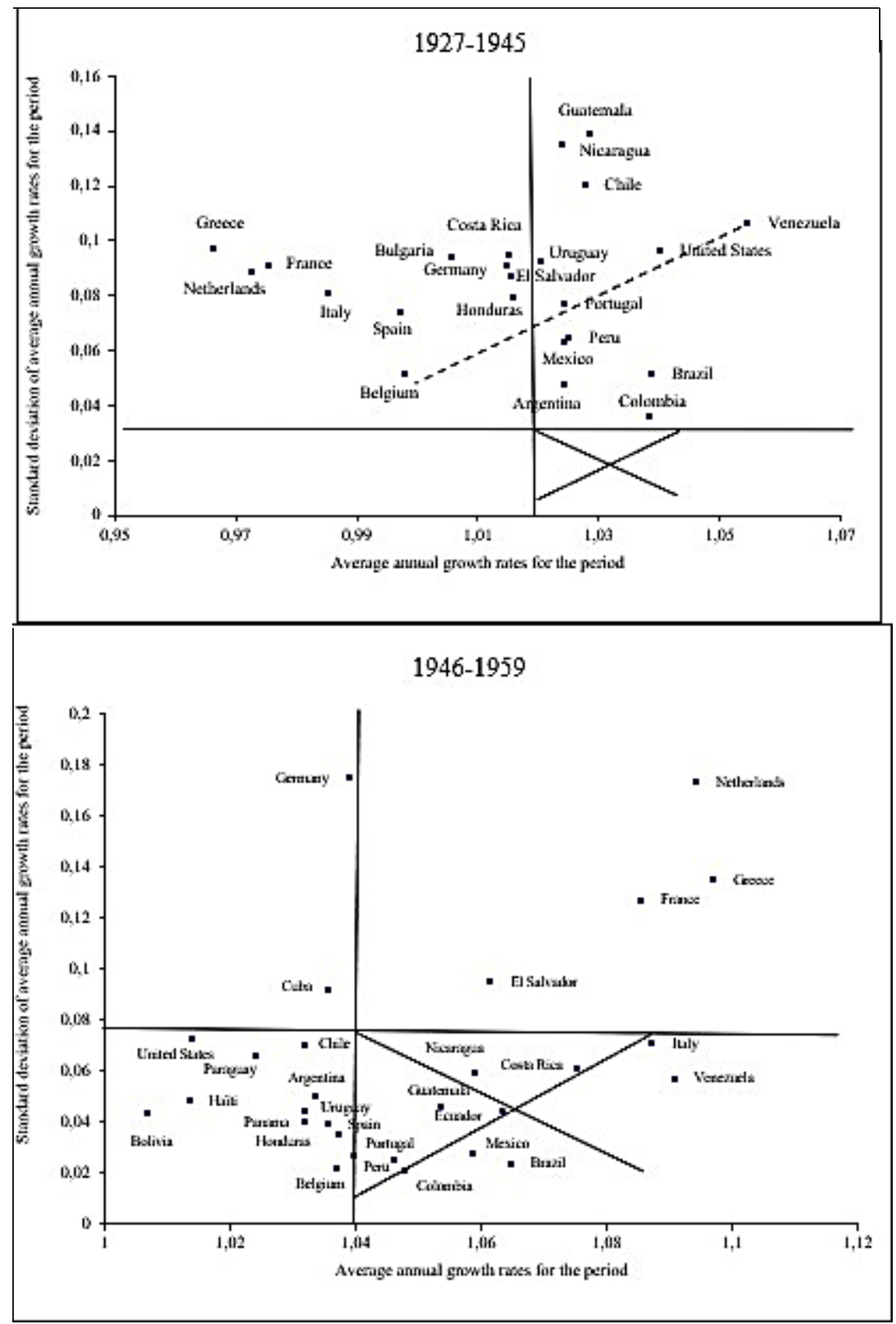




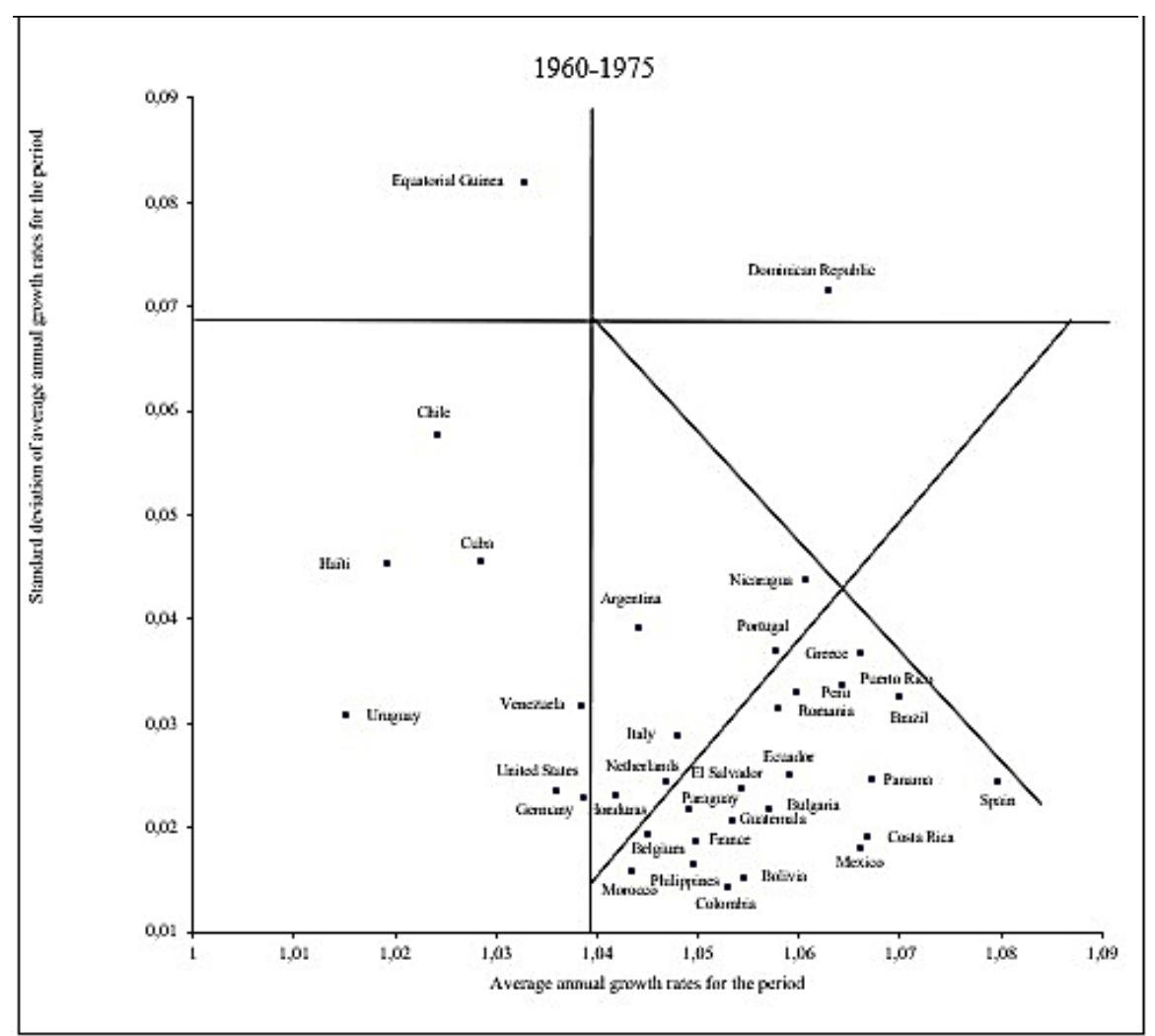


1976-1993

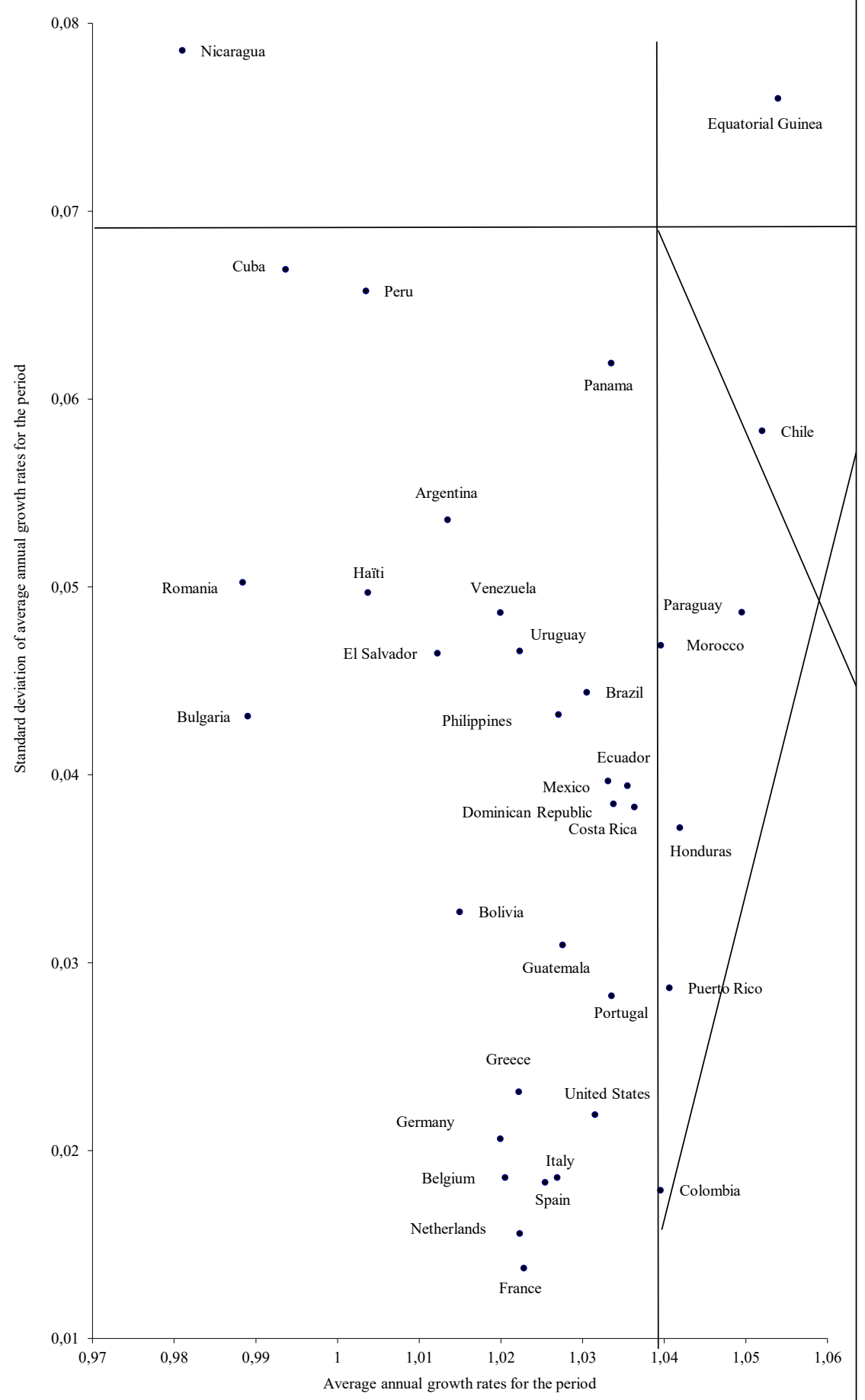



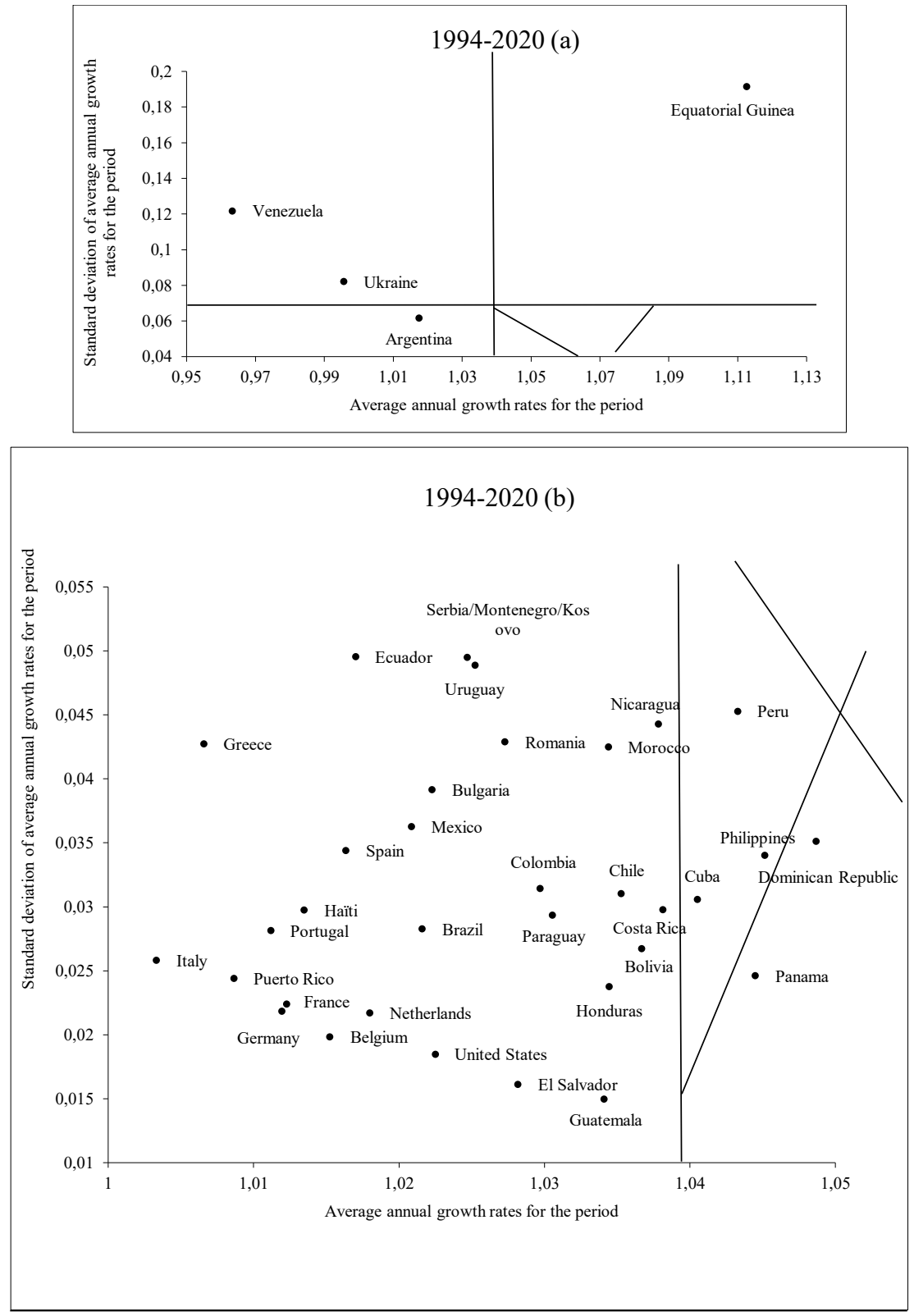

Fig. 2. Economic development of the countries of the Spanish world.

In the 19th century, Spain was in an area of non-innovation. In the first quarter of the 20th century, having escaped the World War, Spain found itself in a conservative position of effective development. The war and subsequent isolation brought Spain back to the area of conservation. During this period, the former Latin American colonies of Spain experienced an economic boom. In 1960-1975, Spain emerged as a leader in economic development, ending up with most of its former colonies in an egalitarian conservative development. The Spanish economy was pumped up with Western investments on the eve of the fall of the dictatorship, in order to prevent the country from moving away from a pro-Western 
orientation. After integration into the European Union, Spain found itself on the periphery of the development of the OECD countries, where some of its former colonies also began to join.

\section{Conclusions}

In general, it can be stated that after the collapse of the Spanish Empire, its parts had different trajectories of development, but for the last 60 years, their development has been synchronized as the periphery of Western civilization. There is no significant influence on the institutional heritage of Spanish institutions and culture in the studied countries. On the contrary, the institutional influence of the leaders of Western civilization dominates concerning the studied group of countries of Spanish culture, but they are not integrated into the core of the economic development of the global West.

\section{Acknowledgements}

The reported study was funded by RFBR, project number 20-010-00869.

\section{References}

1. E. Yasin, Economic issues, 4, 4 (2003)

2. E. Yasin, Economic issues, 5, 4 (2007)

3. N. M. Lebedeva, E. G. Yasin, Foresight, 2, 16 (2009)

4. A. V. Kostina, Culture as a factor of Russian modernization (2015)

5. R. H. Franke, G. Hofstede, M. H. Bond, Strategic Management J., 12, 165 (1991)

6. S. Shane, J. of Business Venturing, 8(1), 59 (1993)

7. Y. M. van Everdingen, E. Waarts, Marketing Letters, 14(3), 217 (2003)

8. G. E. Halkos, N. G. Tzeremes, Int. Review of Applied Economics, 27(5), 656 (2013)

9. R. Khan, P. Cox, Archives of Business Research, 5(2), 85 (2017)

10. G. H. Hofstede, Culture's consequences: Int. differences in work-related values (1980)

11. R. J. S. Dheer, Small Business Economics, 48(4), 813 (2017)

12. P. Moonen, J. of Organizational Change Management, 30(7), 1149 (2017)

13. K. L. Newman, S. D. Nollen, J. of International Business Studies, 27(4), 753 (1996)

14. T. Büschgens, A. Bausch, D. B. Balkin, J. of Product Innovation Management, 30(4), 763 (2013)

15. J. C. Broberg, A. McKelvie, J. C. Short, D. J. Ketchen, Jr., W. P. Wan, J. of Business Research, 66(12), 2574 (2013)

16. C. J. Boudreaux, J. of Entrepreneurship and Public Policy, 6(1), 26 (2017)

17. P. M. Freitas da Silva, A. Moreira, National culture and its relationship with innovation and corruption. Exploring the influence of personal values and cultures in the workplace, 201 (2017)

18. B. B. Allred, W. G. Park, J. of Int. Business Studies, 38(6), 878 (2007)

19. C. Wang, J. of Macroeconomics, 37, 128 (2013)

20. W. C. Lee, S. H. Law, J. Ekonomi Malaysia, 50(2), 167 (2016)

21. W. C. Lee, S. H. Law, Global Economic Review, 46(3), 203 (2017) 
22. I. Rozinskiy, N. Rozinskaya, Economic issues, 1, 142 (2017)

23. Z. Romanova, Economic issues, 1, 107 (2004)

24. A.V. Kuznetsov, Modern Spain: problems and solutions, 101 (2018)

25. M. Y. Savelyev, Multicultural institutionalism: General economic theory of civilizations, The political economy of traditionalism, 488 (2015)

26. M. Savelyev, Problems of regional economy, 3(4), 54 (2020)

27. M. Savelyev, N. Pushina and A. Savchenko, E3S Web Conf., 20803052 (2020)

28. M. Savelyev, N. Pushina and A. Bryndin, IOP Conf. Ser.: Earth Environ Sci., 666062092 (2021)

29. M. Savelyev, V. Ivanov, Yu. Polyakov, E3S Web of Conf., 22205009 (2020)

30. M. Savelyev, E. Kutyashova, A. Savchenko, V. Koretsky and Yu. Polyakov, SHS Web Conf., 10102004 (2021)

31. M. Savelyev, T. Gruzdeva, A. Savchenko, V. Koretsky and N. Pushina, SHS Web Conf., 10102005 (2021)

32. M. Savelyev, N. Sokolova, Yu. Polyakov, IOP Conf. Ser.: Earth Environ Sci., 666062093 (2021)

33. A. Maddison, Historical Statistics of the World Economy: 1 AD (2008)

34. The Conf. Board, Total Economy Database (2019)

35. TED1, https://conference-board.org/ 